Передера Р. В., кандидат ветеринарних наук, Сахарова О. Ю., студент матістратури

Полтавська державна аграрна академія

\title{
ВИРІВНЮВАННЯ МЕДІО-ЛАТЕРАЛЬНОГО ДИСБАЛАНСУ КОПИТ У КОНЕЙ
}

\section{Рецензент - кандидат ветеринарних наук В. П. Плугатирьов}

Наведені причини порушення функиій копит і підбір оптимальних способів лікування диспропориій медіальної і латеральної копитних стінок у коней. Встановлено, що медіо-латеральний дисбаланс зустрічається у $92 \%$ коней із деформаціями копит і супроводжується аритмією рухів, недостатнім виносом кінцівок, інколи кульгавістю та болючістю у плечах, спині, попереку. Основними лікувальними заходами при цій патології є поступове

та поетапне зменшення медіо-латеральної диспропориії й створення форми, щзо відповідає анатомічно-правильним показникам здорового копита.

Ключові слова: коні, кінцівки, копита, деформації, лікування.

Постановка проблеми. Розвиток фермерських господарств і кінного спорту потребує уваги до галузі конярства - важливої складової агропромислового комплексу України, можливості й резерви якої використовуються недостатньо. Значної шкоди коням продовжують завдавати незаразні хвороби, особливо хірургічні. Хворі тварини на тривалий час втрачають працездатність, знижуються їхня господарська цінність та спортивні показники $[2,3]$.

Найбільш частою хірургічною патологією в коней $\epsilon$ хвороби опорно-рухового апарату, що викликані деформаціями копит або $є$ їх наслідками.

Аналіз основних досліджень і публікацій, у яких започатковано розв'язання проблеми. Розповсюдження патології копит у коней висвітлене у доступній нам літературі в 40-70-х роках, коли цей вид тварин відігравав важливу роль в армії та сільському господарстві $[1,5]$. Відтоді вивчення даного питання припинилося. Цим можна пояснити недостатню на сьогодні ефективність терапевтичних заходів при хворобах копит та їх деформаціях. Так, у Західній Європі, згідно з офіційною статистикою, 70 \% спортивних коней отримують щонайменше одну травму за сезон, а дисбаланс копит реєструють у $95 \%$ коней. Причому деформації копит мають серйо- зні наслідки: порушення біомеханіки (зміна конформації, загального балансу, координації, навантаження), неврологічні розлади копит (зміна чутливості стрілки), порушення кровообігу (застійні явища, гіпоксія тканин, розвиток некротичних процесів) $[4,6]$.

Мета і завдання досліджень: встановлення причин порушення функцій копит та підбір оптимальних способів профілактики й лікування дисбалансу копитної стінки у коней.

Матеріали і методи досліджень. Дослідження проводились у приватних та фермерських господарствах Полтавської області на конях різних вікових груп, порід, із різними умовами утримання та експлуатації. Нами було обстежено 165 голів коней шляхом загального огляду (постава кінцівок, їх винос, ритм руху, наявність кульгавості) та місцевого дослідження копита (огляд, планіметрія, тест на болючість). Тваринам із вираженими деформаціями проводили розчистку.

Результати досліджень. Медіо-латеральний дисбаланс копит - це невідповідність довжини внутрішньої та зовнішньої копитних стінок, спричинена нерівномірністю розподілення навантаження на копито, що призводить до його деформації та деструктивних змін усього опорнорухового апарату коня.

У результаті досліджень із 165 (100\%) досліджених коней у 152 (92\%) тварин виявлений медіо-латеральний дисбаланс, причому в 75 (46\%) тварин різниця між зовнішньою і внутрішньою копитною стінками складала більше 1,5 см, із них у 16 (10\%) тварин - понад 4 см.

Проаналізувавши можливі причини виникнення даної патології, ми дійшли висновку, що різні деформації копит розвиваються під впливом різних факторів. Однак більшість із них обумовлені антропогенним впливом. Це включає, перш за все, неправильні умови утримання та експлуатації коней (особливо відсутність моціону та вільного руху по поверхням різного ступеня твердості), відсутність або неправильну розчистку копит, кування. Менша кількість де- 
формацій копит виникає внаслідок анатомофізіологічних породних або індивідуальних особливостей коней, погодних умов, травм та хронічних захворювань опорно-рухового апарату.

При загальному огляді у першу чергу звертали увагу на поставу. Правильна постановка кінцівок характеризується тим, що грудні кінцівки розташовуються паралельно, а осьова лінія, проведена через лопатко-плечевий суглоб, проходить по середині кінцівки, розділяючи іiі на дві рівні частини. При бічному огляді лінія, опущена від середини лопатки, повинна пройти через ліктьовий і путовий суглоби по середині кінцівки. При поставі тазових кінцівок осьова лінія, проведена від середини сідничного бугра, має розділити кінцівку по середині і далі опуститися проти міжм'якушної борозди. При бічному огляді ця лінія торкається бугра п'яткової кістки й опускається на землю за м'якушкою.

Дослідженнями встановлено, що коні, які мали різницю між зовнішньою і внутрішньою копитною стінкою більше 4 см, часто спотикалися, недостатньо виносили кінцівки, спостерігалася аритмія рухів, інколи кульгавість. Такі тварини- часто відмовлялися від руху вперед (при осадженні та поворотах), рідше спостерігали болючість у плечах, спині, попереку.

При місцевому дослідженні, що включав огляд копит та планіметрію, виявляли невідповідність довжини латеральної та медіальної стінок копита (рис. 1).

Слід також відзначити, що незбалансованість копит негативно відображалася не тільки на рівновазі коня, його поставі, рухах, а й призводила до вторинних патологій: різноманітних тріщин копит; запалення копитної кістки, атрофії, гіпотрофії, гіпертрофії стрілки; травм зв'язок і сухожилків дистального відділу кінцівок, артритів, міозитів м'язів спини, артозів та інших.

Відомо, що основним способом лікування деформацій копит $є$ й залишається розчистка. Перед проведенням розчистки ми здійснювали планіметричні дослідження копит із зняттям усіх промірів копита (рис. 2): висота передньої (a), бокових (c, d), п'яткових стінок (в) копита та кути $(\alpha, \beta)$.
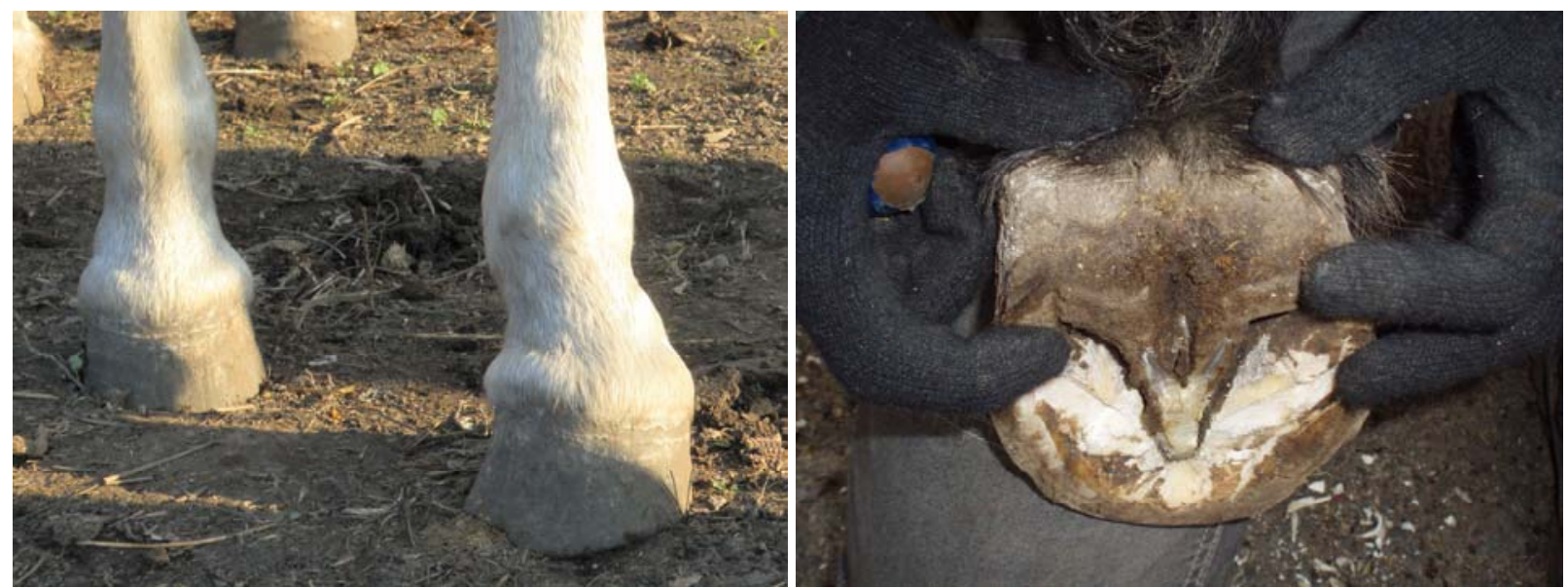

Рис. 1. Медіо-латеральний дисбаланс копит
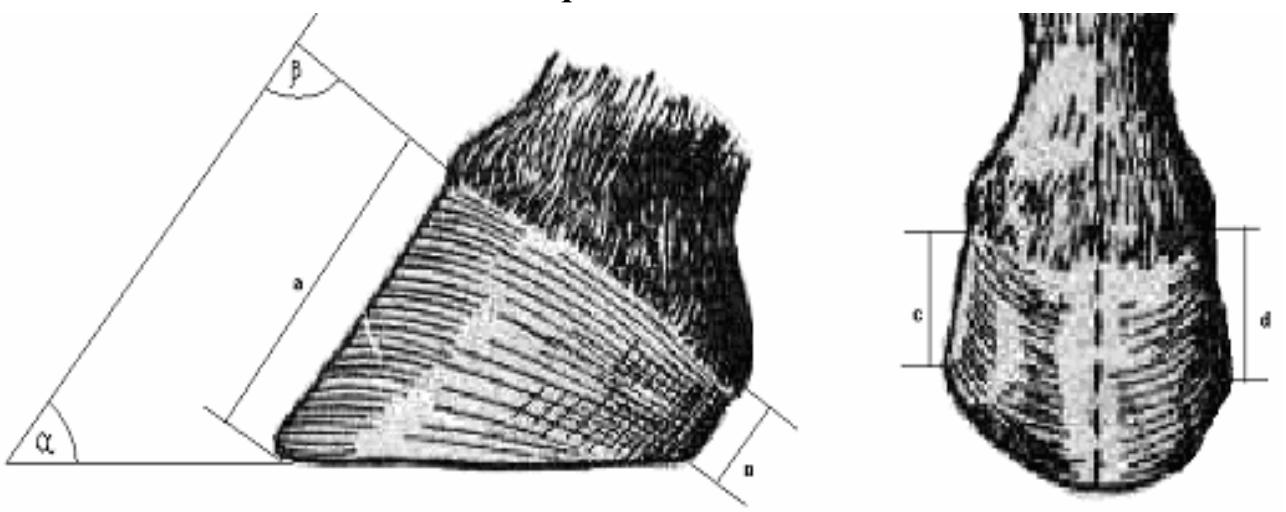

Рис. 2. Основні параметри копит 
При правильній поставі копито на грудних кінцівках розташовується відносно землі під кутом $45-50^{\circ}$, на тазових $-55-60^{\circ}$; співвідношення висоти зачіпної стінки і п'яткової на грудній кінцівці 3:1, а на тазовій - 3:2. Довжина латеральної та медіальної стінок повинна бути однакова.

При розчистці використовували кутиметр та лінійку. Значно полегшувала зняття промірів прозора плівка з нанесеними на ній розмірами.

Після аналізу промірів проводили розчистку 3 урахуванням складності випадку, віку тварини, загального стану, супутніх хвороб тощо. На час лікувальної розчистки звільняли тварин від надмірних навантажень та обмежували їх активність. Однак слід пам'ятати, що різке виправлення копита до фізіологічних параметрів, особливо в медіальному та латеральному напрямку, призводить до низки захворювань кінцівок (тендинітів, тендовагінітів, синовітів). Тому основним принципом нашого лікування була поступова розчистка копит, що забезпечувало адаптацію тварин до перерозподілу навантаження на копито. Частині тварин застосовували лікувальну розчистку, наближену до природної: бокові та п'яткові стінки копит зрізали за допомогою рашпілю або електричної фрези на $0,2-0,3$ см за добу. Інколи повна розчистка копита тривала 4-5 тижнів. Частині коней для зменшення трудомісткості застосували іншу схему: за одну розчистку зрізали не більше $0,5 \mathrm{~cm}$ копитного рогу з інтервалом у 3-5 діб до повного відновлення фізіологічної пропорції копит (рис. 3). Дана схема також зберігала основні принципи лікування.

Як перша, так і друга схеми дали позитивні результати, а саме: після курсу лікувальної розчистки у тварин зникала кульгавість, вони менше стомлювалися, з'явилася ритмічність руху, зменшилась болючість у ділянці попереку; зменшився травматизм цих коней.

\section{БІБЛІОГРАФІЯ}

1. Иванов Н. А. Болезни конечностей и ковка. В кн.: О лошади. - М.: Сельхозгиз, 1937. - Т. 2.$478 \mathrm{c}$.

2. Іздепський В. Й., Стоиький О. Г., Передера Р. В. [ma ін.]. Хірургічні хвороби коней. - Луганськ: Елтон. - 2. - 2010. - 300 с.

3. Кашин А. С. О профилактике и отдельных особенностях травматизма у спортивных лошадей // Хирургические болезни сельскохозяйственных животных: Сб. науч. тр. - Л.,

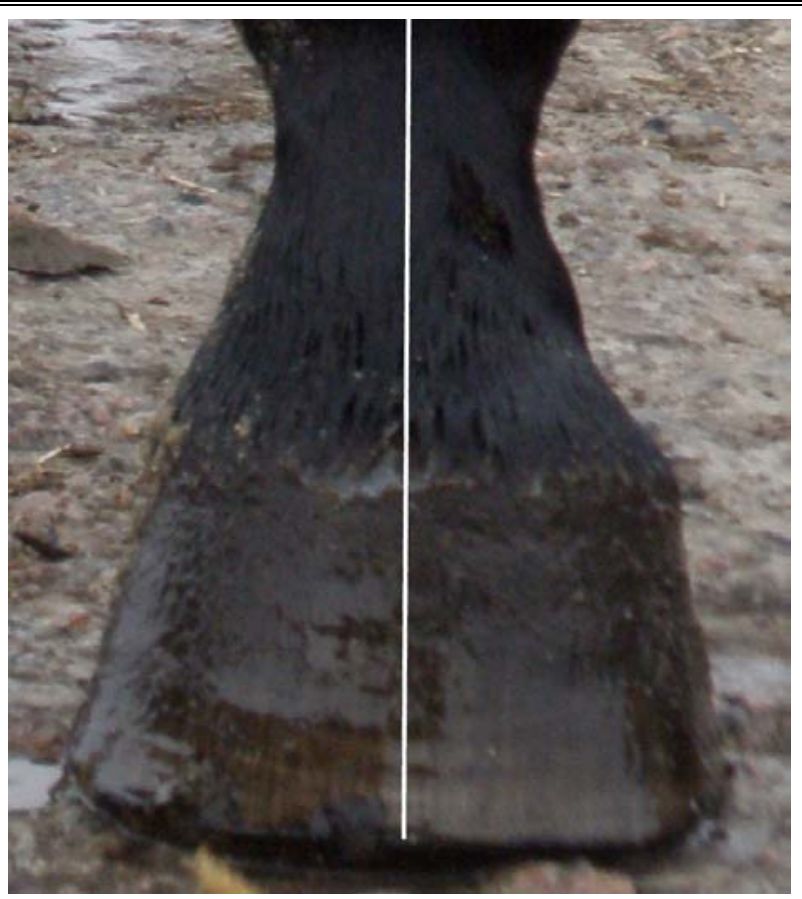

Рис. 3. Правильний баланс копита

Отже, повільне виправлення бокових деформацій копит сприяє поступовому перерозподілу навантаження на сухожилково-суглобовий апарат і дає можливість без ускладнень виправляти складні бокові деформації копит.

\section{Висновки:}

1. Медіо-латеральний дисбаланс зустрічається у $92 \%$ коней із деформаціями копит і супроводжується аритмією рухів, недостатнім виносом кінцівок, інколи кульавістю та болючістю у плечах, спині, попереку.

2. Основними лікувальними заходами цієї патології $є$ поступове та поетапне зменшення медіо-латеральної диспропорції на 0,2-0,3 см щоденно або 0,5 см із інтервалом у 3-5 діб і створення форми, що відповідає анатомічноправильним показникам здорового копита.

1989. - Вып. 102. - С. 202-205.

4. Невзорова Л. А. Как достичь баланса (Nevzorov Haute Ecole: Унгулология). - СПб.: ООО "Невзоров От Эколь", 2009. - 80 с.

5. Оливков Б. М. Общая хирургия домашних животных. - М.: Сельхозгиз, 1954. - 456 с.

6. Стекольников А. А., Семенов Б. С., Молоканов В. И. [u $\partial p$.$] . Ветеринарная ортопедия. - М.:$ Колос, 2009. - 296 с. 